\title{
SEISMIC VULNERABILITY ASSESSMENT OF THE TRIUMPHAL ARCH OF CARACALLA IN VOLUBILIS (MOROCCO): PAST EVENTS AND PROVISIONS FOR THE FUTURE
}

\author{
G. Pancani ${ }^{1}$, S. Galassi ${ }^{1, *}$, L. Rovero ${ }^{1}$, L. Dipasquale ${ }^{1}$, E. Fazzi ${ }^{1}$, G. Tempesta ${ }^{1}$ \\ ${ }^{1}$ Dept. of Architecture, DAR|MED Lab, University of Florence, Italy - (giovanni.pancani, stefano.galassi, luisa.rovero, \\ letizia.dipasquale, eloisa.fazzi, giacomo.tempesta)@unifi.it
}

Commission II - WG II/8

KEY WORDS: Archaelogical Site, Volubilis, Kinematic Analysis, Timeline Reconstruction, Seismic Vulnerability, Safety Assessment

\begin{abstract}
:
The triumphal arch of Caracalla in the Roman archaeological site of Volubilis dates back to 216 AD. It was built in a strategic position at the intersection of the main roads leading to the Forum, the decumanus maximus to the east and the roads from Porte à trios baies to the west, that almost certainly was the main gate to the city. The current arrangement of the monument is the result of a restoration intervention carried out in the 1930s by French restorers. Some ancient photos witness that the monument was just a ruin in 1915 , when Chatelain carried out the former archaeological excavations and, as a consequence, that it was totally rebuilt. In fact, the monument suffered wide damages provoked by the 1755 Lisbon earthquake, that affected also Morocco, which almost completely destroyed it. By means of the drawings made by the travelers Henry Boyde and John Windus, that retraced the monument thirty years before the earthquake, the original configuration of the monument can be observed and the timeline of events can be reconstructed. In this paper, the timeline of the seismic events that affected the triumphal arch is reconstructed and investigated by means of a structural analysis based on a rigid-block model. Finally, with the purpose of preventing future damage, the seismic vulnerability level of the construction is assessed with reference to its current configuration.
\end{abstract}

\section{INTRODUCTION}

The Arch of Caracalla is certainly the most characteristic monument of the archaeological landscape of Volubilis, the main, and best preserved, Roman site in Morocco. Located about $30 \mathrm{~km}$ north of Meknés, Volubilis still shows traces of the Roman colonization of the ancient Berber populations (Galassi et al., 2018a), indigenous races of uncertain origin, probably from Yemen or Palestine. The Romans began to take an interest in them and the city of Volubilis, founded by the Carthaginian merchants in the 3rd century $\mathrm{BC}$, after the destruction of Carthage, so as to ensure the security of the Roman province of Africa, relying on the friendly kingdom of Mauretania.

In $44 \mathrm{AD}$, the kingdom of Mauretania, which included all of the north of the present-day Morocco and much of coastal Algeria, was suppressed, annexed to the Roman Empire, and divided into two provinces, Mauretania Tingitania (that takes its name from the ancient Tingis, now Tangier, in Algeria), corresponding to the north of modern day Morocco, and Mauretania Cesariensis. Thus, Volubilis became the capital of Mauretania Tingitania and one of the major centers of the province. The period of maximum splendour of the city of Volubilis was the third century. In fact, the last years of the kingdom of Caracalla were particularly fervent in the public building sector. In this period the main imperial architectures that today's visitors still enjoy were built: the basilica, the temple of the Capitol and the arch of Caracalla.

The arch of Caracalla was built on the edge of a square at the intersection of the decumanus maximus, the city's main street connecting it to the Porte de Tanger (to the east), and the street leading to the forum, at a distance of less than 100 meters. However, the arch also needed to be accessible from the west, from the Porte à trois baies, considered the main entrance to the city.

Construction began in $216 \mathrm{AD}$ and was completed within just a year. The Latin inscription on the attic explains the reason for its construction, inaugurated by the governor Marcus Aurelieus Sebastenus (Camporeale et al., 2008). Indeed, it is well known that the arch was built in honor of the Roman Emperor Marcus Aurelius Antoninus, nicknamed Caracalla, and his mother, to celebrate Caracalla's grant of the amnesty of overdue taxes owed by all the inhabitants of the province of Mauretania Tingitania and also that it was commissioned by the res publica. In fact, thanks to the numerous inscriptions found in the buildings of Volubilis, the absence of private patrons for the construction of public buildings, for the entertainment of the people and for revering the emperors has been ascertained, thus suggesting that inhabitants preferred to spend their own money to build private homes, furnishings and family tombs.

The monument, in the configuration which can be looked today, is the result of a total reconstruction carried out in the 1930s. In fact, the literature (Cherkaoui et al., 2017) documents not only that the 1975 Lisbon earthquake, which also affected Morocco, caused the almost total collapse of the arch, but also that the reconstruction was carried out with some "freedom of interpretation" (Domergue, 1963), both in terms of the overall height of the monument, which is lower, and in terms of the arrangement of some of the ornamental elements.

\footnotetext{
* Corresponding author
} 
In this paper, the timeline of events that struck the monument is retraced in Section 2, based on historical information taken from the literature (Domergue, 1963; Camporeale et al., 2008; Cherkaoui et al., 2017). Section 3 describes the survey campaign carried out in 2017 (Pancani, 2019) and used to perform the rigid block mechanical model of the structure. In Section 4 the seismic vulnerability of the arch of Caracalla is investigated, exploiting a numerical method implemented in a computer program developed by some of the authors and already applied for the analysis of artifacts preserved in archaeological sites (Galassi et al., 2018b, 2018c).

\section{TIMELINE OF EVENTS}

The first significant sources of documentation of the Volubilis Arch date back to the 18 th century. In particular, the engravings of the western façade of the arch (Figures 1 and 2) which enrich the accounts of two English travellers, Henry Boyde and John Windus, who visited the court of the Sultan of Meknes, both drawn in 1721, show the state of conservation of the monument before the 1755 disastrous Lisbon earthquake.

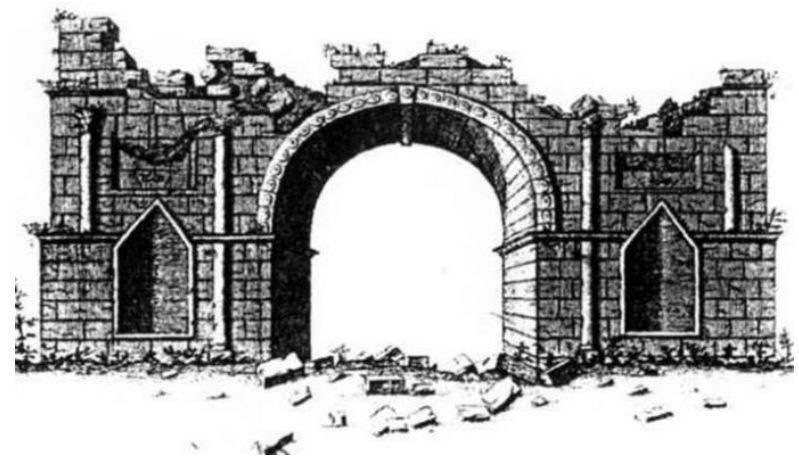

Figure 1. H. Boyde's representation of the arch (1721).

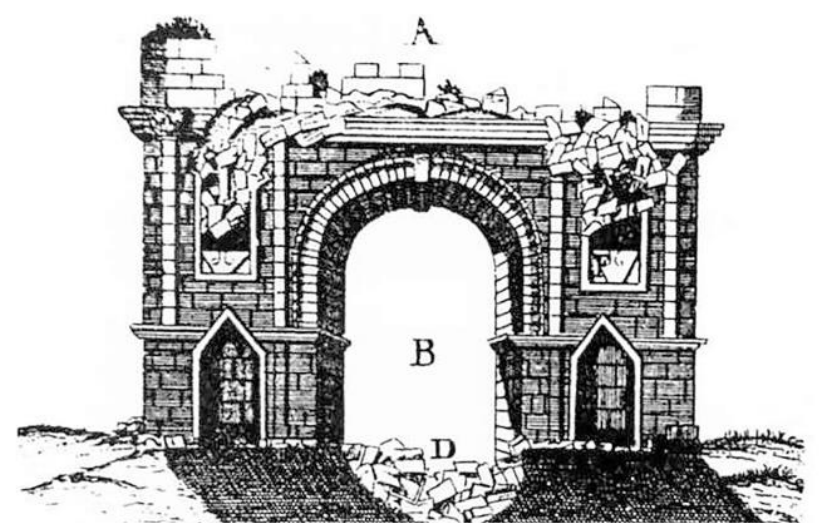

Figure 2. J. Windus' representation of the arch (1721).

From these two images, re-printed in an article by M. Euzennat (Euzennat, 1956), it is evident that the arch, although partially buried, was, in addition to the basilica, the only still recognizable ruin of the ancient Roman city. The structure appeared, in fact, still complete until just above the lintel.

All subsequent documents, however, bear witness to its progressive decay. In a drawing from 1830 (Figure 3), attributed to F. Freihern von Augustin (von Augustin, 1838), the effects of the Lisbon earthquake, which caused the collapse of the vault, leaving only part of the massive piers standing, are clearly visible, as confirmed about 40 years later also by C. J. Tissot (Tissot, 1878) who even provided the main measurements of the monument.

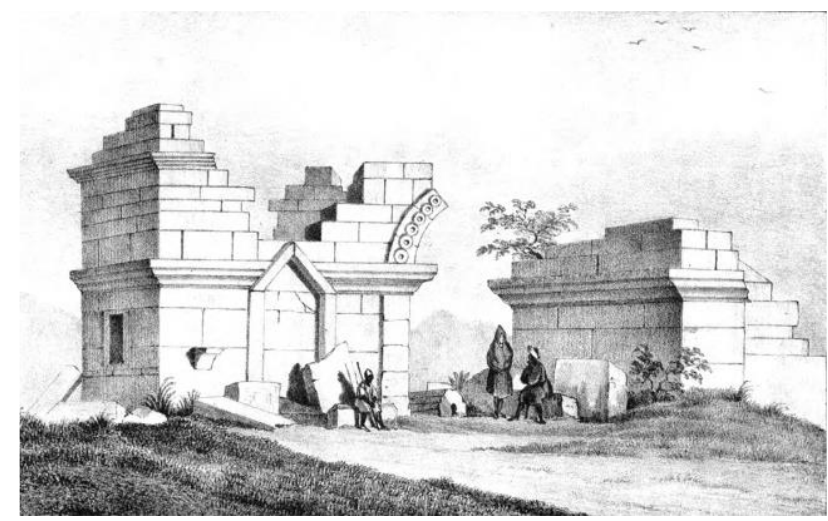

Figure 3. State of the arch in the drawing by F. von Augustin (1823).

In the first photographs published in 1887 (Figure 4), H. de la Martinière documented the state of decay of the arch, showing the collapse of the blocks that were removed from 1915 onwards, when, under the direction of L. Chatelain, French archaeologists began the first excavations.

During these operations, the arch was freed from the rubble and some of the decorative elements were found.

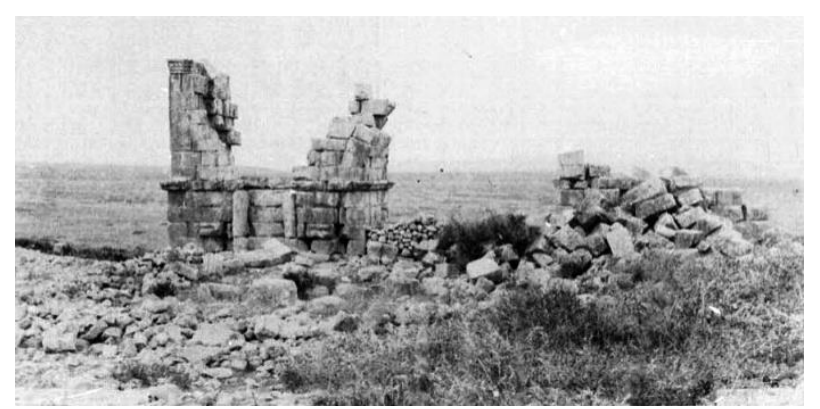

Figure 4. Photo taken by H. de la Martinière (1887).

The restoration, carried out around the 1930s, restored the vault to the monument which thus came to assume its current configuration. We do not have detailed information on the restoration operations carried out in those years, but Chatelain reports that, after numbering the blocks before their removal in order to be able to return them to their original position afterwards, the monument was dismantled (Camporeale et al., 2008). Chatelain also reports that, during reconstruction, a foundation slab was built and that the stone blocks were reassembled and bonded with cement.

However, Domergue (Domergue, 1963) criticised the French restoration on the grounds that the reconstruction of the monument was wrong since, between the lintel and the cornice, only one row of blocks was re-assembled, when instead, from the drawings of English travellers, four rows of preserved stones above the lintel at the left pillar are clearly visible, looking at the west façade. As a result, the current configuration of the monument would appear to be a version of the original shortened in height, which was said to be adorned with a frieze of the height of the four rows of stone blocks mentioned above.

Again, based on the drawings of the two English travellers, Camporeale et al. (2008), in turn, criticised Domergue's hypothesis in which the inscription was on the frieze. The motivation is twofold: on the one hand, the placement of the inscription in the frieze, which is frequently placed on the attic, 
appears unusual; on the other, the representation of the two rows of stone blocks just above the keystone in Boyde and Windus' drawings would exclude the possibility of the placement of the inscription in that point.

Consequently, Camporeale et al. (2008) proposed a new reconstructive hypothesis, identifying some stylistic and geometric "rules". In particular, the Italian archaeologists believe that the module of 2.5 Roman feet (1 Roman foot corresponds to approximately $29.6 \mathrm{~cm}$ ) is the key to understand the geometric layout of the monument. According to this hypothesis, the total footprint of the plan presents a ratio of $65 \times 25$ feet ( $26 \times 10$ modules), the height up to the impost of the vault is 17.5 feet ( 7 modules) while the height measured up to the intrados of the lintel is 30 feet (12 modules). According to this interpretative scheme, the total height of the monument, including the frieze composed of 4 rows of stones, should originally have been 50 feet ( 20 modules), i.e. 14.80 metres, while now, according to the measurements made by the authors (Pancani, 2019a), it appears to be only 9.50 metres (or 11.40 metres if also the inscription is considered).

\section{CONSTRUCTIVE CHARACTERISTICS}

The triumphal monument has a front with a single arch, framed by two massive piers each of which is enriched by two pairs of pedestals that originally supported as many Corinthian columns, of which only two remain today on the eastern front (Figure 5).

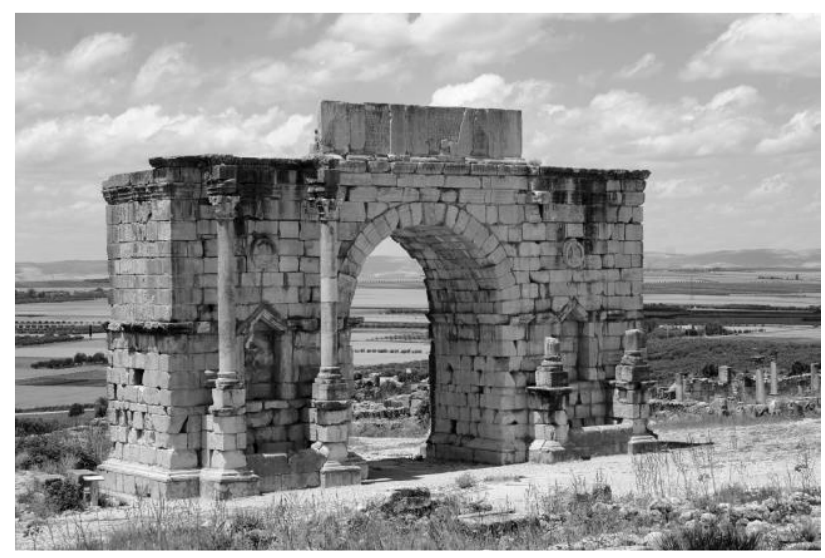

Figure 5. Arch of Caracalla (photo by G. Pancani, 2017).

There is no trace of the lintel originally placed above the eight Corinthian columns, except for some signs still visible along the outer sides of the pillars. Between the columns are some niches, called en bâtière (i.e. pitched), which originally functioned as fountains and poured water into the basins below, no longer remaining.

A Latin inscription walled into the attic, the main source of information on the construction of the monument, is present on the eastern front. Originally, however, this inscription must have been present on both main fronts.

Above the niches/fountains are medallions of the seasons, personified perhaps by the four members of the imperial family Septimius Severus, Julia Domna, Caracalla and Geta. Domergue (Domergue, 1963) criticizes today's arrangement of the medallions, the result of the restoration in the 1930s, theorising their original location in the lost attic, which should also have been surmounted by a bronze monument representing a chariot driven by six horses, according to the inscription.
Only compact limestone extracted from the quarries of Mount Zehroun was used for the construction of the monument, which, given its proximity to the city, allowed the blocks to be transported on ox carts in just three hours (Camporeale et al., 2008). In fact, it is known that local limestone was used for the building site materials of the city of Volubilis, limiting the use of white marble for inscriptions.

Camporeale et al. (2008) were the first to carry out direct measurements of the monument and concluded that, although it is not possible to identify a precise unit of measurement for the size of the stone blocks, the regularity in height of three consecutive rows of 5 feet is recurrent. This solution leads one to think of the ancient builders' knowledge that building perfectly continuous horizontal rows about every metre and a half to regularize the wall texture and arranging the blocks with staggered vertical joints would have brought benefits in the response of the structure to the vertical loads (self-weight). However, the staggering of the vertical joints does not apparently follow any geometrical rule.

It is not yet known whether the monument was made of solid masonry or whether the stone blocks visible on the four fronts were only the outer casing of opus incertum masonry, with a smaller and poorer material core, or whether it was even empty inside. What is certain, is that the first photographs taken by de la Martinière in 1887 and Chatelain in 1915, revealing the state of damage of the arch after the Lisbon earthquake, clearly show the blocks of the outer curtain wall still standing and the lack of the inner core, which leads to the assumption that a dual construction technique was used, at least as regards the portion of masonry placed above the impost line of the vault.

\section{GEOMETRICAL SURVEY}

In May 2017 the author's mission took place in north-eastern Morocco, in the region of Fès-Meknes, during which the Caracalla Arch was studied and measured in detail (Pancani, 2019a,b). A 3D photogrammetric survey based on "Structure from Motion" (SfM) algorithms and completed by direct measurements with traditional instruments, was carried out to graphically render both the overall dimensions of the monument and the dimensions of each block of stone.

The equipment used for the photographic filming needed to create the 3D Mesh Model, consisted of a Sony Alpha 900 camera, digital equipment equipped with a Full-Frame 24 x 36 $\mathrm{mm}$ sensor allowing an effective resolution of 24 megapixels with a maximum image size of $6048 \times 4032$ pixels. In addition to this, two lenses were used: the SonyG SAL 70-400 mm f/4;5.6 SSM tele-zoom at a fixed focal length of $200 \mathrm{~mm}$ for filming the top of the arch, from a distance of about 70 metres, to reduce the effects of foreshortening on the wall face as much as possible and the Sony SAL 24-70mm f/2.8 SSM Zeiss Vario Sonnar T* zoom lens to shoot the base and sub-arch part at focal lengths between 35 and $55 \mathrm{~mm}$. The differentiation of the lenses and focal lengths used was required in order to obtain images as close up as possible.

Photographs were taken during the central hours of the day to make the most of natural light and a dataset of 250 photos with the images overlapping by about $70 \%$, was obtained. These photos were processed using the 3DF Zephyr (3DFlow, 2019) software which implements the SfM algorithms mentioned above and which reconstructed the so-called point cloud, subsequently used to generate the 3D Mesh Model. The texture obtained from 
the photos was applied to this, so as to provide a detailed description of the state of conservation of the stone materials. Lastly, the textured model was projected onto planes parallel to the fronts of the arch to generate the orthophotos.

The main plan, elevation and cross-section dimensions obtained from the survey operations are shown in Figures 6,7 and 8, while Figures 9 and 10 show the orthophotos of the eastern elevation and the side elevations.

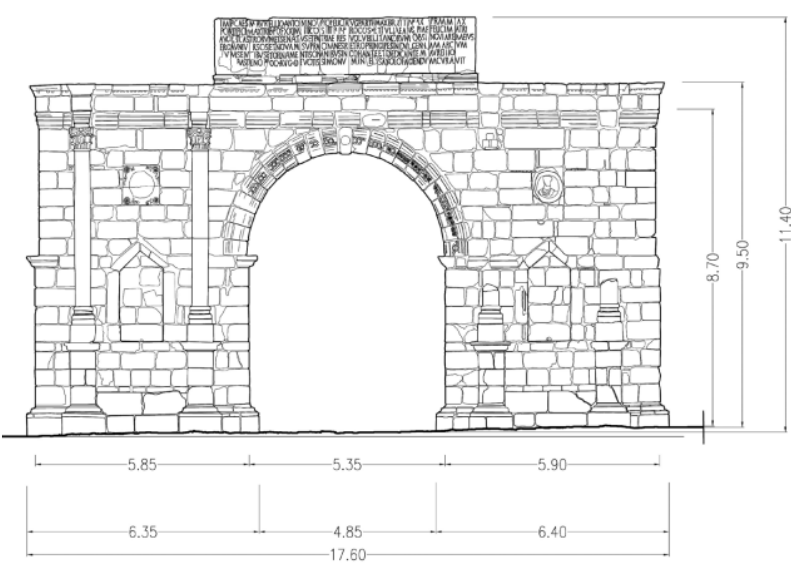

Figure 6. Eastern elevation (from the 2017 survey).

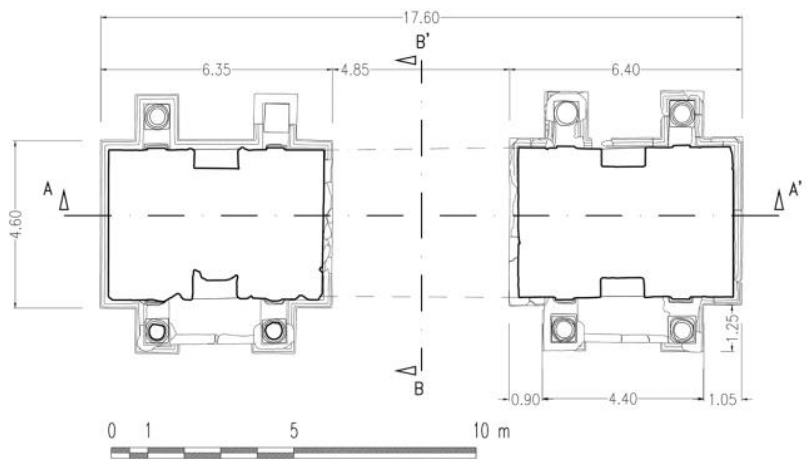

Figure 7. Plan (from the 2017 survey).
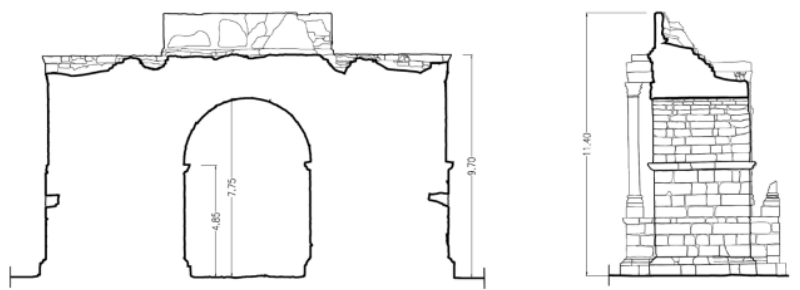

Figure 8. Longitudinal cross-section and north elevation (from the 2017 survey)

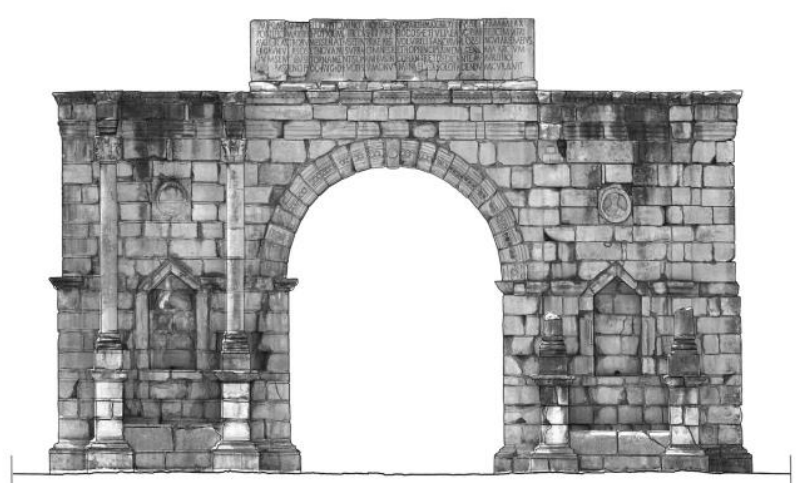

Figure 9. Orthophoto of the eastern elevation (from the 2017 survey).
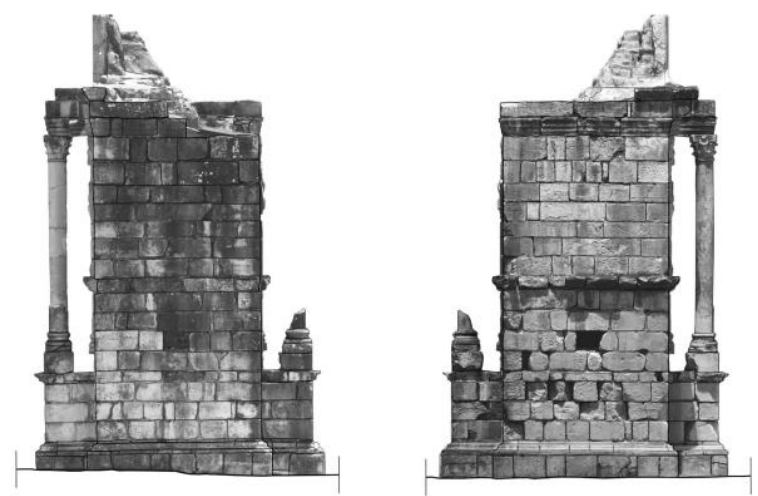

Figure 10. Orthophoto of the north (a) and south (b) elevations (from the 2017 survey).

\section{RIGID-BLOCK ANALYSIS AND SEISMIC VULNERABILITY}

In its life-cycle, the monument was severely damaged by earthquakes several times, which ruined it almost completely. The main cause of this damage was certainly the 1755 Lisbon earthquake, which affected also Morocco seriously. After the main quake of November 1st, with epicentre in the Atlantic Ocean, which caused numerous victims especially along the coast due to the tsunami that was generated as a result, the replica of November 18 caused the death of many people especially in Fès and Meknès, where the buildings were already severely damaged from the previous quake. Lastly, a new earthquake, with epicentre near Meknès, even stronger than the previous one, occurred only a few days later, on November 27th. The archaeological site of Volubilis was almost entirely destroyed by these subsequent events and the condition of the arch is that shown in Figure 4.

In this section the results of the seismic vulnerability assessment of the triumphal arch carried out by the authors are presented, aimed not only at retracing the timeline of the events, occurred in the 18th century, that severely damaged it, but also to provide information on the vulnerability level of the monument in its current state.

In the literature, various procedures have been proposed for the analysis of masonry constructions, subject to foundation settlements or seismic actions, and generally they have been used for specific structural types, such as stand-alone vaults and domes (e.g. Block et al., 2006; Betti et al., 2008; Pugi et al., 2013; Cavalagli et al., 2016, Galassi et al., 2017; Pantò et al., 2017; 
Giresini et al., 2017; Marmo et al., 2017; Misseri et al., 2017; 2018; Zampieri et al., 2019a, 2019b) or, in most cases, they have been used for standard constructions, that is "complete", such as buildings (e.g. Uva et al., 2006; Salerno et al., 2009; Caliò et al., 2012; Hofer et al., 2016; Portioli et. al, 2017; Cascini et al., 2018; Ciocci et al., 2018; Arrighetti, 2019). However, given the peculiarity of archaeological sites, where constructions often occur as ruins and are, therefore, detached from the original context (which has previously collapsed) that can no longer provide a boxlike behaviour nor act as constraint, this specificity must be taken into account in the modeling. The authors have assessed the seismic vulnerability of the arch of Volubilis using a software specially developed and capable of representing the peculiarity of remains in archaeological sites, named BrickWORK (Galassi et al., 2018b, 2018c).

\subsection{The computer program BrickWORK}

The monument has been modeled by a set of rigid blocks, linked together and to the soil by means of elastic joints in such a way as to take into account the presence of the cement mortar used to bond the blocks during the restoration works carried out in the 1930s or, anyway, of a different mortar that was also probably originally present. Therefore, the mechanical model of the structure is a model with elasticity concentrated in the joints.

In turn, the joints are modeled through an interface device composed by two links orthogonal to the interface $\left(n_{1}\right.$ e $\left.n_{2}\right)$, which transfer the axial force $X_{n}$, and two links arranged along the interface $\left(t_{1}\right.$ e $\left.t_{2}\right)$, which transfer the shearing force $X_{t}$ (Figure 11).

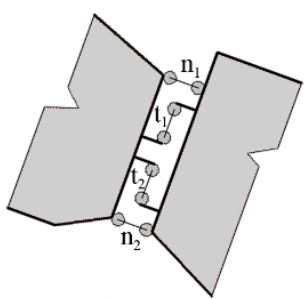

a)

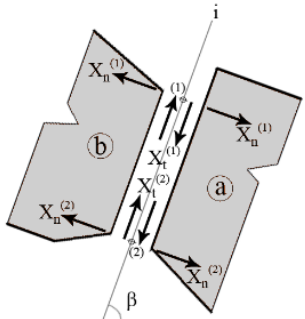

b)
Figure 11. Joint device between block 'a' and 'b' of the mechanical model.

The system of equations that governs the mechanical behavior of the structure can be expressed, in matrix form, through an equilibrium equation and an elastic-kinematic equation (Eq. 1):

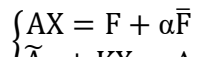

In the equilibrium equation (the first one), A is the geometrical configuration matrix, $\mathrm{F}$ is the vector of the dead loads and $\overline{\mathrm{F}}$ is the vector of the external loads that are increased by the factor $\alpha$. In the specific case of the arch of Volubilis, $\overline{\mathrm{F}}$ is the pattern of horizontal loads provoked by the earthquake and $\alpha$ is the seismic factor.

In the elastic-kinematic equation (the second one), $\tilde{A}$, the transpose of matrix A, is the kinematic equation, $K$ is the diagonal matrix whose entries are the deformability coefficients of the links of the joint device. Vectors $\mathrm{X}$ and $\mathrm{x}$ are the static and kinematic unknowns of the problem, the former being the vector of the forces in the interface links and the second one being the vector of the horizontal, vertical and rotational displacements of the block centroids. Vector $\Delta$ is the "distortion" vector and its use in the numerical procedure will be discussed later.
Two failure criteria are assigned to the interface links. Stresses in the axial links $X_{n}$ cannot overcome the threshold value of the tensile strength (which is zero in the case of a no-tension material) and stresses in the shearing links $X_{t}$ cannot overcome the threshold value of the shearing strength, that activates sliding blocks, computed according to the Coulomb criterion.

The solution of Eq. 1 is shown in Eq. 2, which provides the values of the forces of the links of the joint devices:

$$
\mathrm{X}=\mathrm{X}_{0}+\left(\mathrm{I}-\mathrm{K}^{-1} \widetilde{\mathrm{A}}\left(\mathrm{AK}{ }^{-1} \widetilde{\mathrm{A}}\right)^{-1} \mathrm{~A}\right) \cdot \Delta
$$

where Eq. 3 is the linear-elastic solution:

$$
\mathrm{X}_{0}=\mathrm{K}^{-1} \widetilde{\mathrm{A}}\left(\mathrm{AK}^{-1} \widetilde{\mathrm{A}}\right)^{-1} \cdot(\mathrm{F}+\alpha \overline{\mathrm{F}})
$$

The numerical procedure is iterative. At the beginning of the analysis vector $\Delta$ is initialized to zero, therefore the initial solution corresponds to that of Eq. 3, that is $\mathrm{X}=\mathrm{X}_{0}$.

Afterwards, it is necessary to check, in Eq. 2, if the forces in the axial and shear links do not exceed the corresponding strengths. For this purpose, vector $X$ is partitioned in the two sub-vectors $X_{n}$ and $X_{t}$ whose entries are the forces in the links orthogonal to and along the joint respectively and the tensile failure criteria are formulated in Eq. 4:

$$
\left\{\begin{array}{c}
\mathrm{X}_{\mathrm{n}}^{(\mathrm{j})} \leq \bar{\sigma}_{\mathrm{n}} \cdot \mathrm{S}^{(\mathrm{j})} \\
\mathrm{X}_{\mathrm{t}}^{(\mathrm{j})} \leq \mathrm{f} \cdot \mathrm{X}_{\mathrm{n}}^{(\mathrm{j})}
\end{array}\right.
$$

in which $\bar{\sigma}_{\mathrm{n}}$ is the tensile strength of the joint, $f$ is the friction factor and $S$ is the area of the cross section of the j-th link.

If the solution provided by Eq. 2 does not agree with the constraint of Eq. 4, the analysis becomes nonlinear and the procedure must nullify, step by step, the inadmissible forces and vector $\mathrm{X}$ in Eq. 2 is computed again each time.

In order to nullify the inadmissible force of a link, the numerical procedure introduces an "impressed distortion" into that link. The set of impressed distortions introduced into the links whose forces do not satisfy the conditions expressed by Eq. 4 is composed of the non-zeroes coefficients of vector $\Delta$.

At each step of the iterative analysis entries of vector $\Delta$ are unknown. To compute the entries of vector $\Delta$ to be input in Eq. 2 , this equation has been re-written partitioning all matrices and vectors considering the coefficients corresponding to the links with admissible forces (subscript "b") and the links with inadmissible forces (subscript "c") and putting $\mathrm{C}=(\mathrm{I}-$ $\left.\mathrm{K}^{-1} \widetilde{\mathrm{A}}\left(\mathrm{AK}{ }^{-1} \widetilde{\mathrm{A}}\right)^{-1} \mathrm{~A}\right)$ :

$$
\left[\begin{array}{c}
\mathrm{X}_{\mathrm{b}} \\
0
\end{array}\right]=\left[\begin{array}{c}
\mathrm{X}_{0 \mathrm{~b}} \\
\mathrm{X}_{0 \mathrm{c}}
\end{array}\right]+\left[\begin{array}{cc}
\mathrm{C}_{\mathrm{b}} & \mathrm{B} \\
\widetilde{\mathrm{B}} & \mathrm{C}_{\mathrm{c}}
\end{array}\right] \cdot\left[\begin{array}{c}
0 \\
\Delta_{\mathrm{c}}
\end{array}\right]
$$

The solution of Eq. 5 provides the sub-vector of the "effective distortions" (Eq. 6) and the sub-vector of the final solution collecting the non-zero forces (Eq. 7):

$$
\begin{aligned}
& \Delta_{\mathrm{c}}=-\mathrm{C}_{\mathrm{c}}^{-1} \mathrm{X}_{0 \mathrm{c}} \\
& \mathrm{X}_{\mathrm{b}}=\mathrm{X}_{0 \mathrm{~b}}-\mathrm{BC}_{\mathrm{c}}^{-1} \mathrm{X}_{0 \mathrm{c}}
\end{aligned}
$$


Finally, in order to draw the final configuration of the structure, the effective displacement vector $\bar{x}$ and the vector $\bar{\Delta}_{\mathrm{c}}$ that measures the depth and position of cracks in the mortar joints are computed considering both the links that elastically deformed and those that failed. In this purpose, the second of Eq. 1 is partitioned considering once again the links with admissible and inadmissible forces:

$$
\left[\begin{array}{ccc}
\widetilde{\mathrm{A}}_{\mathrm{b}} & \mathrm{K}_{\mathrm{b}} & 0 \\
\widetilde{\mathrm{A}}_{\mathrm{c}} & 0 & \mathrm{~K}_{\mathrm{c}}
\end{array}\right]\left[\begin{array}{c}
\overline{\mathrm{X}} \\
\mathrm{X}_{\mathrm{b}} \\
0
\end{array}\right]=\left[\begin{array}{c}
0 \\
\bar{\Delta}_{\mathrm{c}}
\end{array}\right]
$$

The solution of Eq. 8 provides the vector $\mathrm{x}$ of the displacements of the block centroids (Eq. 9 ) and the vector $\bar{\Delta}_{\mathrm{c}}$ that measures the depth and position of cracks in the mortar joints (Eq. 10):

$$
\begin{gathered}
\overline{\mathrm{x}}=-\mathrm{K}_{\mathrm{b}} \mathrm{X}_{\mathrm{b}} \mathrm{A}_{\mathrm{b}}\left(\widetilde{\mathrm{A}}_{\mathrm{b}} \mathrm{A}_{\mathrm{b}}\right)^{-1} \\
\bar{\Delta}_{\mathrm{c}}=\widetilde{\mathrm{A}}_{\mathrm{c}} \overline{\mathrm{x}}
\end{gathered}
$$

\subsection{Seismic vulnerability of the triumphal arch}

The model of the triumphal arch of Caracalla has been performed adopting a discretization in macro-elements that follows the actual arrangement of blocks and joints, in order to reduce the computational effort. The load condition has been defined considering the self-weight of the blocks. The unit weight has been roughly appraised considering the overall weight of the monument computed by Camporeale et al. (2008) equal to 1350 tons, based on the hypothesis that only the piers are made of solid masonry and that above the impost line of the vault the monument would consist of outer leaves of blocks with an inner empty core. According to it, the unit weight of $27 \mathrm{kN} / \mathrm{m}^{3}$ is obtained, perfectly coherent with the reference values from the literature that range between 24 and $27 \mathrm{kN} / \mathrm{m}^{3}$.

To perform the seismic vulnerability assessment, a pattern of horizontal forces, proportional to the masses of the blocks and linearly variable as a function of the height of their point of application, has been inputted in the mechanical model, acting leftward (-X direction).

In order to assess the current vulnerability level of the monument, the value of the seismic factor $\alpha$ that activates the collapse mechanism was computed considering as reference model the current geometry of the arch (Figure 12).

Figure 13 shows the collapse mechanism of the structure plotted by the program and the results of the analysis are presented in the first row of Table 1 , that shows the collapse factor $\alpha_{0}$, the participating mass $\mathrm{M}^{*}$ and the spectral acceleration $\mathrm{a}^{*}$ of activation of the mechanism.

\begin{tabular}{|l|l|l|l|l|}
\hline \multicolumn{1}{|c|}{ Event } & $\begin{array}{c}\text { Earthquake } \\
\text { direction }\end{array}$ & \multicolumn{1}{c|}{$\alpha_{0}$} & \multicolumn{1}{c|}{$\mathrm{M}^{*}$} & \multicolumn{1}{c|}{$\mathrm{a}^{*}$} \\
\hline Main quake & $-\mathrm{X}$ & 0.168 & $90,358 \mathrm{~g}$ & $0.017 \mathrm{~g}$ \\
\hline $2^{\text {nd }}$ phase & $+\mathrm{X}$ & 0.145 & $111,920 \mathrm{~g}$ & $0.016 \mathrm{~g}$ \\
\hline $3^{\text {rd }}$ phase & $-\mathrm{X}$ & 0.168 & $412,682 \mathrm{~g}$ & $0.017 \mathrm{~g}$ \\
\hline
\end{tabular}

Table 1. Results of the analysis.

Figure 13 clearly shows that the vault and the left side of the right pier are the former portions that collapse, while the left pier suffers wide damages. The vulnerability of the structure is explained by the lack of a monolithic behaviour of the right pier, which suffers a sudden diagonal crack that provokes, in turn, the collapse of the vault.
The computed value of the spectral acceleration points that the structure can resist a very low intensity earthquake and, therefore, that the preservation of the monument is currently at risk.

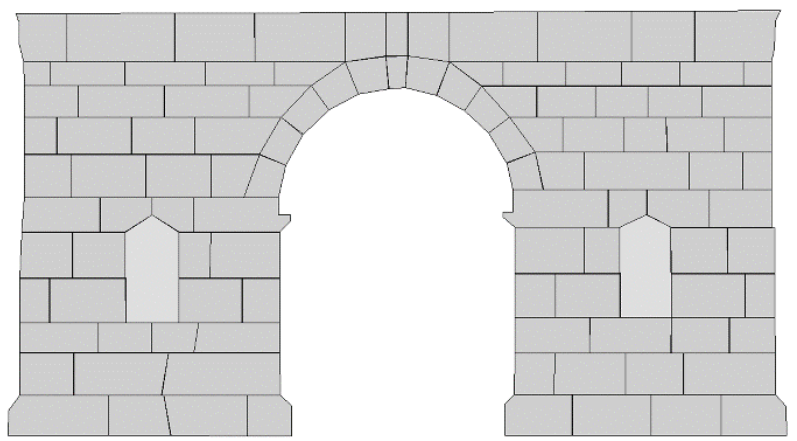

Figure 12. Mechanical model of the arch in its current configuration.

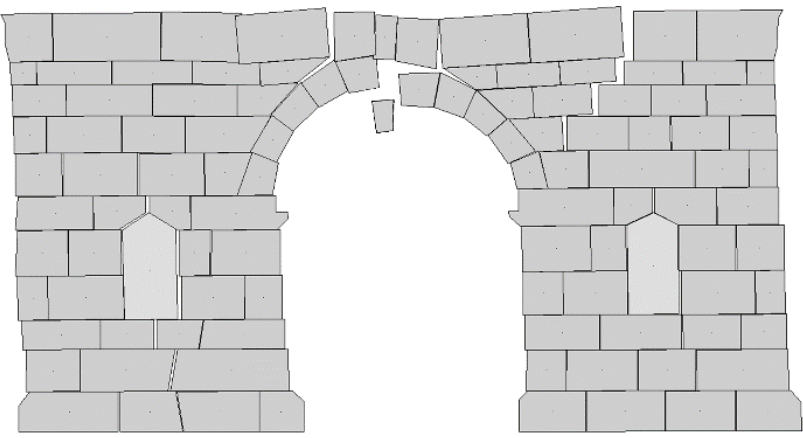

Figure 13. Collapse mechanism and current seismic vulnerability.
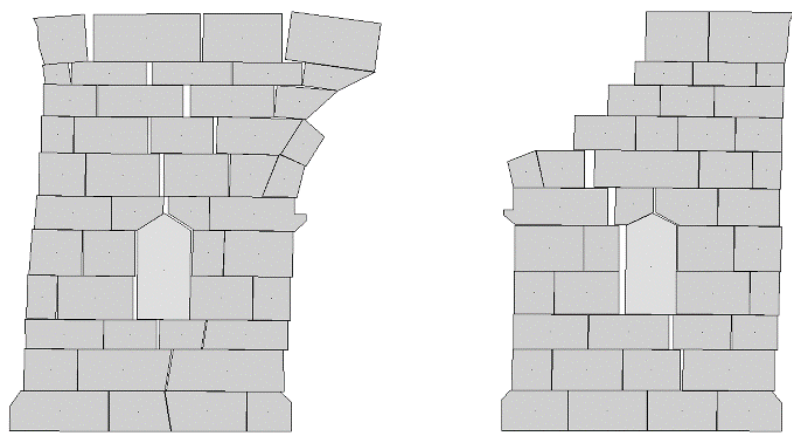

Figure 14. Structure damaged during the 2 nd phase.
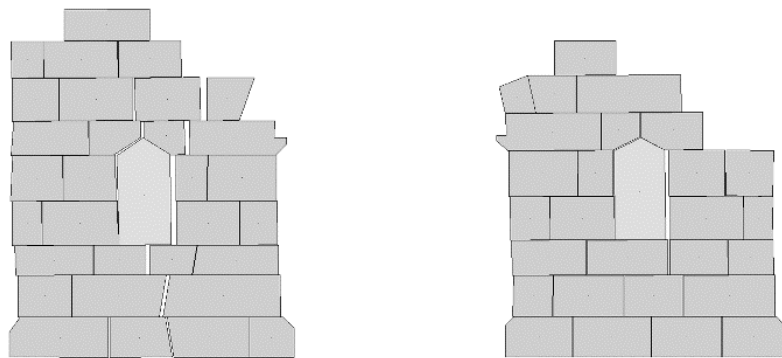

Figure 15. Structure damaged during the 3 rd phase. 
Finally, in order to follow the timeline of seismic events that affected the monument in the 18th century, the model in figure 13 has been taken as the new reference structure for the analysis. Indeed, such a model is effectively capable of describing the damage suffered by the monument during the first choc of the 1755 earthquake.

In order to consider the cyclic effect of the seismic action, the analysis has been rerun, inputting the horizontal forces rightward ( $+\mathrm{X}$ direction). The model has been analyzed several times, each time removing from the model the blocks collapsed at the previous step and reversing the direction of the horizontal forces $(-X,+X)$. Results of the phases analyzed are listed in the $2^{\text {nd }}$ to $3^{\text {rd }}$. Figures 14 and 15 show the structure damaged during the second and the third phase.

Since the purpose of the analysis was exactly the reconstruction of the subsequent events qualitatively, to perform the analysis the authors used a model made of rigid blocks assembled with elastic joints, but the elastic modulus was not calibrated suitably and no soil effect was considered. The assumptions of no-tension and infinite compression strength and the lack of values of the property of the soil certainly leads to a conservative result, provided by values of the spectral acceleration that are rather low. In this regard, the obtained results of the current seismic vulnerability of the monument, which can be described by the first analysis shown in figure 12 and 13, necessary to provide information useful to prevent further collapses in the future, must be considered conservative as well. A more in-depth analysis, based on the knowledge of the properties of materials and the soil, which significantly affect the seismic response (Rovero et al., 2016; Alecci et al., 2019; Viti et al., 2019), should be carried out. By doing so, the current seismic vulnerability can also be carried out according to the Moroccan Règlement de Construction Parasismique RPS 2000-Version 2011 (RPS 2000), which divides the national territory of Morocco into five homogeneous seismicity zones (from 0 to 4), and the archaeological site of Volubilis is located in the $2^{\text {nd }}$ zone, that is characterized by an expected seismic acceleration equal to $0.16 \mathrm{~g}$.

\section{CONCLUSIONS}

In this paper the results of a geometrical, historical and structural investigation on the triumphal arch of Caracalla in the archaeological site of Volubils is presented.

In particular, the article focuses on the reconstruction of timeline of events that caused the collapse of the monument during the 18 th century earthquake.

The timeline of events was reconstructed using a numerical model developed by the authors for the analysis of ruins in archaeological sites, capable of identifying the damage and collapse mechanisms provoked by an earthquake effectively.

The analysis carried out provided conservative results because a dry-assembled-like masonry was assumed, due to the nil value of tensile strength of mortar.

An in-depth analysis of the current vulnerability of the monument could be carried out based on the comparison between the capacity and the demand, this last one being expressed according to the current Moroccan building code and considering both the soil effect and the properties of mortar joints suitably calibrated in such a way as to simulate the actual strains of the brickwork of the triumphal arch of Caracalla.

\section{ACKNOWLEDGEMENTS}

The research activity herein developed is framed within the international agreement between the School of Architecture of Fez (EMADU), Euro-Mediterranean University of Fez, Morocco, and the School of Architecture, University of Florence, Italy. This analysis is part of the activities of the research unit Dar|Med, from the University of Florence.

\section{REFERENCES}

Alecci, V. Stipo, G., La Brusco, A., De Stefano, M., Rovero, L., 2019: Estimating elastic modulus of tuff and brick masonry: a comparison between on-site and laboratory tests, Constr. Build. Mater., 204, 828-38.

Arrighetti, A., 2019: Registering and documenting the stratification of disruptionsand restorations in historical edifices. The contribution of archaeo-seismology to architecture, $J$. Archaeol. Sci. Rep., 23, 243-251. doi.org/10.1016/j.jasrep.2018.10.028.

Augustin, F.F. von, 1838: Erinnerungen aus Marokko, gesammelt auf einer reise im Jabre 1830, Vienne, Echaumburg.

Betti, M., Drosopoulos, G.A., Stavroulakis, G.E., 2008: Two non-linear finite element models developed for the assessment of failure of masonry arches, CR Mecanique, 336(1,2), 42-53.

Block, P., Ciblac, T., Ochsendorf, J.A., 2006: Real-time limit analysis of vaulted masonry buildings, Comput. Struct., 84(2930), 1841-1852. doi: 10.1016/j.compstruc.2006.08.002.

Caliò, I., Marletta, M., Pantò, B., 2012: A new discrete element model for the evaluation of the seismic behaviour of unreinforced masonry buildings. Eng. Struct. 40, 327-38. doi:10.1016/j.engstruct.2012.02.039.

Camporeale, S., Papi, E., Passalacqua, L., 2008: L'organizzazione dei cantieri a Volubilis (Mauretania Tingitana): iscrizioni e opere pubbliche, la Maison aux deux pressoirs e l'arco di Caracalla, in Camporeale S., Dessales H., Pizzo A., Arqueología de la construcción I, "Los procesos constructivos en el mundo romano: Italia y provincias occidentales", Mérida, Consejo Superior de Investigaciones Científicas, pp. 285-308.

Cascini, L., Gagliardo, R., Portioli, F., 2018: LiABlock_3D: A Software Tool for Collapse Mechanism Analysis of Historic Masonry Structures. Int. J. Archit. Herit., 14(1), 75-94. doi.org/10.1080/15583058.2018.1509155.

Cavalagli, N. Gusella, V., Severini, L., 2016: Lateral loads carrying capacity and minimum thickness of circular and pointed masonry arches, Int. J. Mech. Sci., 115, 645-56.

Cherkaoui, T.E., El Hassani, A., Azaoum, M., 2017: Impacts du tremblement de terre de 1755 au Maroc: histoire, société et religion, in : «Testemunhas do Caos as Factes do Terramoto de $1755 »$, M. T. Antunes and J. L. Cardoso (Eds.), Academia das Ciências de Lisboa, Portugal.

Ciocci, M.P., Sharma, S., Lourenco, P.B., 2018: Engineering simulations of a super-complex cultural heritage building: Ica Cathedral in Peru, Meccanica, 53, 1931-1958. doi.org/10.1007/s11012-017-0720-3. 
Domergue, C., 1963: L'Arc de triomphe de Caracalla àVolubilis, in École pratique des hautes études. $4^{e}$ section, Sciences historiques et philologiques. Annuaire 1963-1964, 283-293.

Euzennat, M.: 1956, Deux voygeurs anglais au Maroc (1721), Hespéris, XLIII, Paris, pp. 325-334.

Galassi, S., Misseri, G., Rovero, L., Tempesta, G., 2017: Equilibrium analysis of masonry domes. On the analytical interpretation of the Eddy-Lévy graphical method, Int. J. Archit. Herit., 11(8), 1195-1211. doi: 10.1080/15583058.2017.1372823.

Galassi, S., Ruggieri, N., Dipasquale, L., Tempesta, G., 2018a: Assessment of the Moroccan Vernacular Timber Roof: a Proposal for an Eco-Friendly Strengthening System, Journal of Architectural Conservation, 24(3), 224-248. doi.org/10.1080/13556207.2018.1545105.

Galassi, S., Ruggieri, N., Tempesta, G., 2018b: A novel numerical tool for seismic vulnerability analysis of ruins in archaeological sites, Int. J. Archit. Herit., 14(1), 1-22, doi.org/10.1080/15583058.2018.1492647.

Galassi, S., Ruggieri, N., Tempesta, G., 2018c: Ruins and archaeological artifacts: vulnerabilities analysis for their conservation through the original computer program BrickWORK, in: "Structural Analysis of Historical Constructions", Aguilar, R., Torrealva, D., Moreira, S., Pando, M., Ramos, L.F. (eds.), RILEM bookseries 18, Springer International Publishing, pp. 1839-1848. doi.org/10.1007/978-3319-99441-3_197, Proc. of 11th International Conference on structural analysis of historical constructions (SAHC2018)(11-13 September 2018, Cusco, Perù).

Giresini, L., Sassu, M., Butenweg, C., Alecci, V., De Stefano, M., 2017: Vault macro-element with equivalent trusses in global seismic analyses, Earthquakes and Structures, 12(4), 409-423.

Heyman, J., 1969: The safety of masonry arches, Int. J. Mech. Sci., 11(4), 363-85, doi.org/10.1016/0020-7403(69)90070-8.

Hofer, L., Zampieri, P., Zanini, M.A., Faleschini, F., Pellegrino, C., 2018: Seismic damage survey and empirical fragility curves for churches after the August 24, 2016 Central Italy earthquake, Soil Dyn. Earthq. Eng., 111, 98-109. doi.org/10.1016/j.soildyn.2018.02.013.

Marmo, F., Rosati, L., 2017: Reformulation and extension of thethrust network analysis, Comput. Struct., 182, 104-118. doi.org/10.1016/j.compstruc.2016.11.016.

Misseri, G., Rovero, L. 2017: Parametric investigation on the dynamic behaviour of masonry pointed arches, Arch. Appl. Mech., 87(3), 385-404.

Misseri, G., DeJong, M. J., \& Rovero, L. 2018: Experimental and numerical investigation of the collapse of pointed masonry arches under quasi-static horizontal loading, Eng. Struct., 173, 180-190.

Pancani, G., 2019: L'arco di Caracalla a Volubilis, in: "Studi su architetture, ambienti e città dell'Europa", A. Robotti (Ed.), Edizioni Grifo, Lecce, Italy.
Pancani, G., Galassi, S., Bigongiari, M., Zuppanti, G., 2019: Geometrical survey and historical, morphological and structural investigations of the Caracalla's Triumphal Arch in the archaeological site of Volubilis (Morocco), Proc. of RIPAM 2019 International Conference, 20-22 November 2019, Rabat, Morocco.

Pantò, B., Cannizzaro, F., Caliò, I., Lourenço P.B., 2017: Numerical and experimental validation of a $3 \mathrm{D}$ macromodel for the in-plane and out-of-plane behavior of unreinforced masonry walls, Int. J. Archit. Herit., 11(7), 946-64.

Portioli, F. Cascini, L., 2017: Large displacement analysis of dryjointed masonry structures subjected to settlements using rigid block modelling. Eng. Struct., 148, 485-496.

Pugi, F., Galassi, S., 2013: Seismic analysis of masonry voussoir arches according to the Italian building code. Ingegneria Sismica - Int. Journal of Earthquake Engineering, Patron, 30(3), 33-55.

Rovero, L., Alecci, V., Mechelli, J., Tonietti, U., De Stefano, M., 2016: Masonry walls with irregular texture of L'Aquila (Italy) seismic area: validation of a method for the evaluation of masonry quality, Mater. Struct., 49 (6), 2297. doi.org/10.1617/s11527-015-0650-2.

RPS (Royaume du Maroc, Ministère de l'Habitat et de la Politique de la Ville). 2000. Règlement de Construction Parasismique. RPS 2000-Version 2011. Decreto n. 2-02-177 du 9 hija 1422 (22 febbraio 2002). Djibouti, Africa: RPS.

Salerno, G., de Felice, G., 2009: Continuum modeling of periodic brickwork, Int. J. Solids Struct., 46, 1251-1267.

Tissot, C.J., 1878: Recherches sur la géographie comparée de la Mauritanie Tingitane, in: "Mémoires présentés par divers savants à l'Académie des inscriptions et belles-lettres de l'Institut de France », première série, sujets divers d'érudition, tome $9,1^{\mathrm{e}}$ partie, pp. 139-322.

3DFlow, 3DF Zephyr Pro, release 4.523, https://www.3dflow.net/it/3df-zephyr-modelli-3d-da-fotosoftware-di-fotogrammetria-e-scansione-3d/

Uva, G. Salerno, G., 2006: Towards a multiscale analysis of periodic masonry brickwork: a FEM algorithm with damage and friction, Int. J. Solids Struct., 43, 3379-3769.

Viti, S., Tanganelli, M., D'Intinosante, V., Baglione, M., 2019: Effects of Soil Characterization on the Seismic Input, $J$. Earthq. Eng., 23(3), 487-511. doi.org/10.1080/13632469.2017.1326422

Zampieri, P., Amoroso, M., Pellegrino, C., 2019a: The masonry buttressed arch on spreading support, Structures, 20, 226-236. doi.org/10.1016/j.istruc.2019.03.008.

Zampieri, P., Simoncello, N., Pellegrino, C., 2019b: Seismic capacity of masonry arches with irregular abutments and arch thickness, Constr. Build. Mater., 201, 786-806. doi.org/10.1016/j.conbuildmat.2018.12.063. 